OAK RIDGE NATIONAL LABORATORY

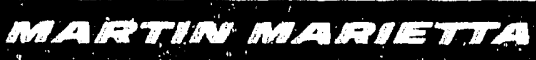

\title{
Nuclear Medicine Program Progress Report for Quarter Ending September 30, 1991
}

F. F. Knapp; dr.
K. A. Ambrose
A. Hasan
A. P. Callahan
C. R. Lambert
D. W. McPherson
S. J. Lambert
S. Mirzadeh
D. E. Rice
P. C. Srivastava 
This report has been reproduced directly fram the best available copy.

Available to DOE and DOE contractors from the Office of Scientffic and Tectini. cal Information, P.O. Box 62, Oak Fladge, TN 37831; prices available from (615) 578.8401, FTS 626.8401.

Available to the public from the National Technical Information Service; U.S. Department af Commerce, 5285 Port Royal Rd., Springfield, VA 22161.

This report was prepared an an account of work sponsored by an agency of the United States Government. Neither the United States Government nor any egency thereot, nor any of their employees, makes any warranty, express or implied, or ausumes any legal liability or responsibility for the acruracy, completeness, or usefuiness of any information, alparatus, product, or process disclosod, or represents that its use would not infringe privately owned rights. Feference herein to any specitic commercial product; procese; or service by trade name, trademnic, manufacturer, or otherwise, does not necessarily constltute or imply ito endorsement, recommendation, or favoring by the United States Government or any agency thereot. The viewa and opinions of authors expreseed hercin do not necessarily state or reflect those of the United States Government or any agency thereot. 
Contract No. DE-ACO5-840R21400

Health and Safety Research Division

NUCLEAR MEDICINE PROGRAM PROGRESS REPORT

FOR QUARTIER ENDING SEPTEMBER 30, 1991

F. F. Knapp, Jr., Group Leader

K. R. Ambrose

A. P. Callahan

D. W. McPherson

S. Mirzadeh

P. C. Srivastava
A. Hasan
C. R. Lambent
S. J. Lambert
D. E. Rice

Work sponsored by DOE Office of Health and Environmental Research:

DATE PUBLISHED: FEBRUARY 1992

OAK RIDGE NATIONAL LABORATORY

Oak Ridge, Tennessee 37831-6285 managed by MARTIN MARIETTA ENERGY SYSTEMS, INC. for the U.S. DEPARTMENT OF ENERGY 
Prexrious reponts in this series:

ORNL/MM-5809:

ORNL/TM-5936

ORNI/TM-6044

ORNL/TML6118.1

ORNL/TM-6371

ORNL/TM-6410

ORNL/TM-6638

ORNL/TM-6639

ORNL/TM-6771

ORNL/TM-69116

ORNL/TM-6958

ORNL/TML7072

ORNL/TM-7:223

ORNL/TM-7411

OR'NL/TM-7,482

ORNL/TM-7605

ORNL/TM-7685

ORNL/TML-7775

ORNL/TM-7918

ORNL/TM-8123

ORNL/TM-8186

ORNL/TM-8363

ORNL/TM-8428

ORNL/TM-8533

ORNL/TM-8619

ORNL/TM-87/46

ORNL/TM-8827

ORNL/TM-8966

ORNL/TM-9037

ORNL/TM-9124

ORNL/TM-9343

ORNL/TM-19394

ORNL/TM-9480

ORNL/TM- 9609

ORNL/TM-9707

ORNL/TM-91784

ORNL/TM-9937

ORNL/TM-10082

ORNL/TM-10238

ORNL/TM-10294

ORNL/TM-10377

ORNL/TM-10441

ORNL/TM-10618

ORNL/TM-10771

ORNL/TM-10839

ORNL/TM-11014
ORNL/TM-111043

ORNL/TM-111145

ORNL/TM-11224

ORNL/TML-111304

ORNL/TML111377

ORNL/TM-111427

ORNL/TM-111550;

ORNL/TM-11570:

ORNL/TM-11721

ORNL/TM-11755

ORNL/TM-11830)

ORNL/TM-111881i 


\section{CONTENTS}

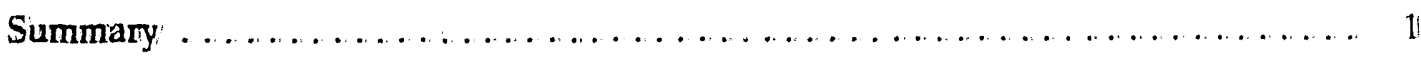

Biodistribution Studies with 1-Azabicyclo\{2:2:2\}oct-3-yll $\alpha$-Hydhoxy-a-phenylt $a$-(11-iodo-11-propen-3-yll)acetate (IQNP), A New Ligand for the Study of Muscarinic Receptor Populations ........................... 2

Aigents Fr Medical Coopenatives $\ldots \ldots \ldots \ldots \ldots \ldots \ldots \ldots \ldots \ldots \ldots \ldots \ldots \ldots \ldots \ldots$

Other Nuclear Medicine Gnoup Activities . .......................... 6 , 
In this report the nat tissue distribution properties of "rONP;"' a new radioiodinated cholinergic-muscaninic receptor antagonist, are described. IQNP is the acronym for 1-azabicycib[2:2.2]bet-3-yll $a$-hydhoxy-a-phenyl-a-(11-iodo-1-propen-3-yll)acetate; which is an analbgue of the QNB muscaninic antagonist in which the puiodophenyll moiety has been replaced with the 1-iodo-1-propen-3-yl moiety. The radioiodinated IQNP' analbgue is easien to prepare in much higher yields: than QNB and is thus a candidate for the evaluation of muscarinic receptors by external imaging techniques.

Studies in nats demonstrated that IQNP shows high uptake in those cenebnall regions rich in muscarinic receptors, (at $6 \mathrm{~h}$; contex $=0.47 \%$ dose $/ \mathrm{gm}$; cortex $/$ cerebellum $=7.83$ and cortex/blood $=2: 24$ ). In addition, QNB-treatment of rats either $1 \mathrm{~h}$ before (pre) on 2 h a atter (post) administration of radioiodinated IQNP resulted in significant displacement or blocking of cerebral specific IQNP uptake (\% dose/gm) in the cortex and striatum (at 3 h, striatum: control $=0.40$, pre $=0.03$, post $=0.10 ;$ contex control $=0: 47$, pre $=0.03$, post $=0.114) \mathrm{L}$ Areas of non-specific uptake were not as greatly affected (at 3 h, cerebellum: control $=0.09$; pre $=0: 02$; post $=0: 03$ ). Other blocking studies with ligands with established necepton specificity indicated that IQNP was only displaced ty those ligand's with established muscarinic receptor specificity (e.g., QNB and dexetimide). These combined studies demonstrate that IQNP has specificity for the cholinergic-muscarinic receptor and is a good candidate tor funther strudies.

Also during this period, several agents developed in the ORNL Nuclear Medicine Program were supplied to Medical Cooperative Programs for collaborative studies including: the iodine-125-labeled BMIPP and DMMPP fatty acid analogues and the IPM antibody labeling agent. In addition, tin-117 m and gold-199 ware produced in the ORNL Hight Flux. Isotope Reactor (HIFIR) and supplied to the OHER-supported program in the Medical Department at Brookhaven National Laboratory to aid in their reseanch until the re-start of the High Flux Brookhaven Reactor. 
BIODISTRIBUTTION STUDIES WITH 1-AZABICYCLO[2:2:2]OCT-3-YL, $\alpha$-HYDROXY- $\alpha$-PHENYL- $\alpha$-(11-IODO-11-PROPEN-3-YL))ACETATE (IQNR)h,

A NEW LIGAND FOR THE STUDY OF MUSCARINIC RECEPTOR' POPULATIONS

The muscaninic acetylcholine receptor system appears to play an important role in various physiological and behavional processes, in addition to various dementias such as Altheimer's disease. These observations have prompted the development of radiolabeled muscarinic receptor specific ligands for use in Computed Tomognaphic studies. We have previously reported the synthesis of a new ligandi (ORNL/TM-11881) 1-azabicyclo[2:2:2]bct-3yll $\alpha$-hydhoxy-a-phenyl-a-(11-iodo-1-propen-3-yl)acetate (IQNP) (11), an analogue of 1-azabicyclb[2.2.2] $]$ ct-3-yll $\alpha$-hydroxy-a, $\alpha$-diphenylacetate (QNB), a potent muscarinic antagonist.<smiles>CC(O)(CC(=O)OC1CN2CCC1CC2)c1ccccc1</smiles>

Scheme I.

Biodistribution studies with ${ }^{125}$ IQNP were performed using female Fisher VAF rats $(-125 \mathrm{~g})$ over a $6 \mathrm{~h}$ period. [ $[-125] \mathrm{QNP}$ was dissolved in $0.1 \mathrm{ml}$ of ethanol and 0:05 $\mathrm{ml}$ of IN HCl was addedi. The solution was diluted to $10 \mathrm{ml}$ with normal saline, passed through a 0.22 nicron Millipore filter andinjected through a tail vein into the metofane-anesthetizedi animals $(1-2 \mathrm{mCi})$. The animals were killed by cervical fracture at the designated time points, and the various organs removed, rinsed with saline, blotted dry, and weighed in tared vials. The brains were immediately dissected into the various anatomical regions upon removal. Samples were counted in a Packard Minaxi 5000 sodium iodide auto gamma counter. The results are summarized in Table 1. 
These data demonstrate that IQNP' has a higher uptake in brain tissues that ane rich in muscarinic receptors: (contex andi striatum)) with lbwer uptake in tissues that do not have a high concentration of these receptors: (cerebellum)). There: is; a modest uptake of radioactivity/ by/ the heart tissue; which also, contains a high concentration of muscaninic receptors:

Table 1. Biodistribution of ${ }^{125}$ IQNP' in Female Fisher V/AF Rats $((\%$, dose/gm)).**

\begin{tabular}{|c|c|c|c|c|c|c|}
\hline \multirow[b]{2}{*}{ Organi } & \multicolumn{6}{|c|}{ Time $(\min ))$} \\
\hline & 16 & 30 & 601 & 1201 & $240)$ & 364 \\
\hline Blbod: & $0.85 \pm 0115$ & $0,62 \div 005$ & $0.38 \pm 0.05$ & $0.38 \pm 0.08$ & $0.27 / \pm 0.04$ & $0.211 \pm 0102$ \\
\hline Liven & $1 ! 46 \pm 0.18$ & $1.10 \div 0.05$ & $0.80 \pm 0.06$ & $0195 \pm 0 \times 04$ & 0.76E+0108: & $0,65 \pm 0,07]$ \\
\hline Kidhey, & $5 i 09 \pm 0160$ & $295 \div 0 / 27$ & $1.40 \pm 0122$ & $0.67 / 40.07 /$ & $0.30 \div 0104$ & $0 / 2040102$ \\
\hline Heart & $1.44 \pm 0114$ & $1.111 \pm 0.06$ & $0.777 \pm 0105$ & $0168 \pm 005$ & $0.28 \pm 0203$ & $0: 17 \pm 0 \times 02$ \\
\hline Lung; & $4119 \pm 0148$ & $294 \pm 0117 /$ & $1.60 \pm(0) 15$ & $0.96 \pm 0.13$ & $0,36 \pm 0.04$ & $0.22 \pm 0102$ \\
\hline Cortex: & $0,99 \pm 0 \times\left(6^{3}\right)$ & $0.80 \pm 0 \times 09$ & $0.86 \pm 0005$ & (1)64_0102. & $0.54 \pm 0104$ & $0.477 \pm 0106$ \\
\hline Striatum & $0: 82 \geq 0: 10$ & $0 \times 69 \pm 01111$ & $0.86 \pm 0 / 111$ & (1)98 \pm 0112 . & $0.52 \pm 0.04$ & $0.41 \pm 0.07 /$ \\
\hline Cerebellium & $0.54 \pm 0.05$ & $0.36 \pm 0 \times 02$ & $0130 \pm 0102$ & $0124 \pm 0 \times 011$ & $0.09 \pm 0 \times 01$ & $0.06 \pm 0.01$ \\
\hline Rest of Brain & $0.72 \pm 0306$ & $0.53 \pm 0.04$ & $0.58 \pm 0.07$ & $0 / 411 \pm 0.03$ & $0132 \pm 0102$ & $0.27 \div 40203:$ \\
\hline
\end{tabular}

Mean I standard deviation 5, rats/time pointi.

A series of experiments were also conducted to determine if the uptake of IQNP cnuld be blocked by $\mathrm{QNB}$, a potent muscarinic antagonist. This experiment consisted of the preinjection of QNB ( $(5 \mathrm{mg} / \mathrm{kg}), 1 \mathrm{~h}$ before the injection of ${ }^{125} \mathrm{IQNP}$ to evaluate what effect the injection of a muscarinic antagonist would have on the uptake of IQNP. Another set of animals was injected with ${ }^{125} \mathrm{IQNP}$ followed by injection of QNB $(5 \mathrm{mg} / \mathrm{kg}) ; 2 \mathrm{~h}$ later to determine if the binding of IQNP to the receptor site was: reversible. As a control, some animals received only the ${ }^{125}$ IQNP injection. Three hours after the injection of IQNP the animals were killed, the brain and heart removed, dissected into the various aneas of interest, and counted. The results of this study are shown in Figure 1 .

The results of this study demonstrate that the uptake of IQNP is blocked by the preinjection of a muscarinic antagonist, and that the uptake of IQNP is displaceable by muscarinic antagonist. These results suggest that IQNP demonstrates selectivity; for the muscarinic receptor, and that this binding to the muscarinic receptor is reversible. 


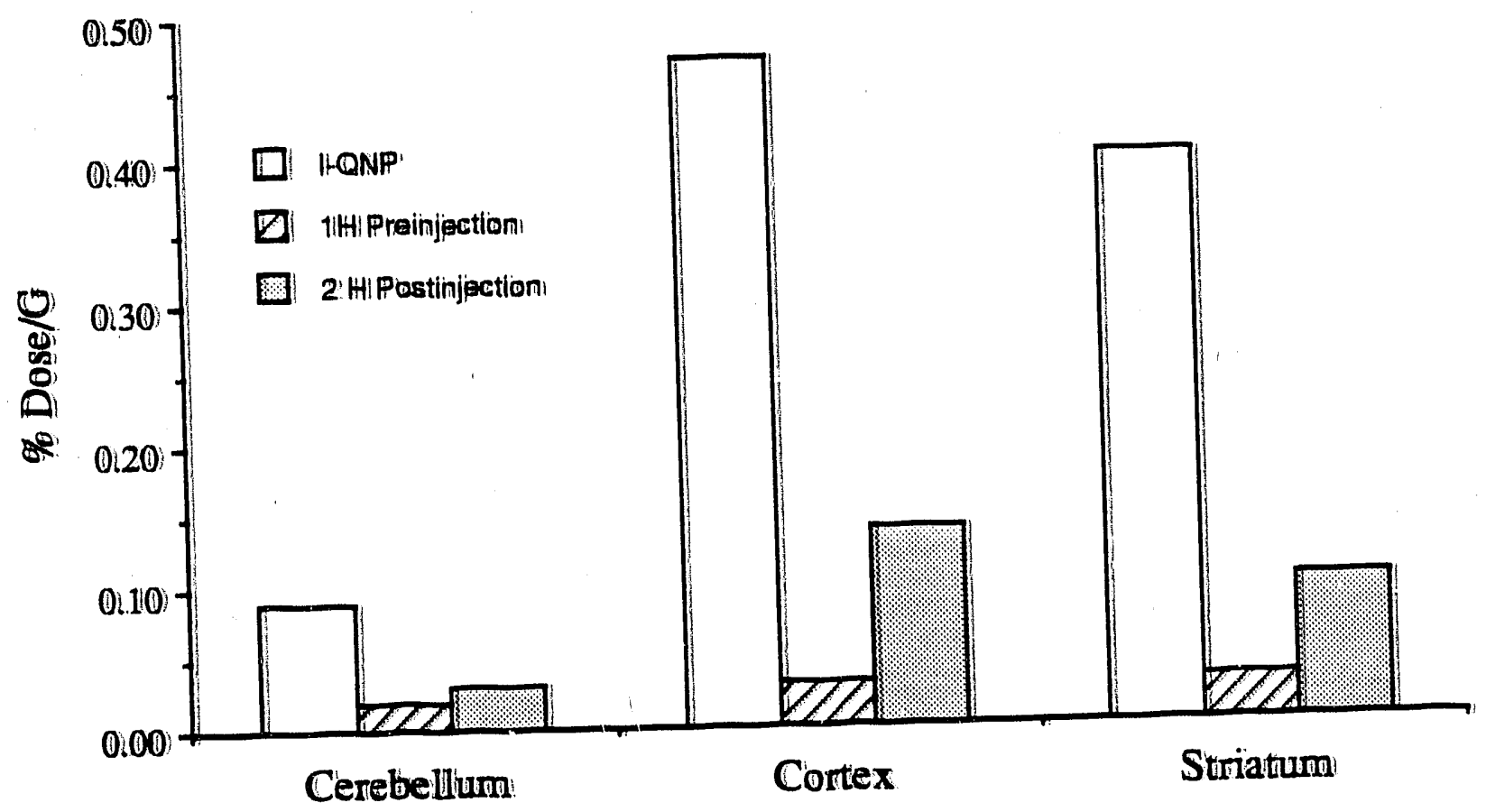

Figure 1. Comparison of the uptake of radfoactivity/ in the cerebellum, cortex, andi striatum after injection of iodine-125-QNP' (control) with animals treated before or after with the QNB muscarinic antagonist.

A study to determine the specificity of IQNP' binding, for the muscaninic recepton was: also perfomed using a series of blbcking agents for different receptors (Figure 2). In this study, each challenge: ligand ( $5 \mathrm{mg} / \mathrm{kg}$ ) ) was injected into a set of animals; and after $1 \mathrm{~h}$ a solution of ${ }^{125}$ IQNP' was then injected. After 3 , $h$, the animals; were sacrificed, the various: ongans of interest removed and counted. The ligands; and receptor specificity used for this study/ were: spiperone (D2 dopamine antagonist)), ( + ) -butaclamol (D2/D11 dopainine antagonist), (-) -butaclamol (inactive enatiomer), ONB (muscarinic antagonist)h, dexetimidie (muscaninic antagonist) $)$, and ketanserine ( $5 \mathrm{HT}_{2}$, serotonin antagonist).

These results: show that only/ QNB and dexetimide; both muscaninic antagonists, block the uptake of IQNP demonstrating that IQNP demonstrates specificity for the muscaninic receptor: The otther blocking agents showed no sffect on the uptake of IQNP into recepton 
mich aneas of the brain. Further studies utilizing, IONP' as a muscaninic receptor imaging agent in langer animals; utilizing imaging andl autonadiogpaphic tecthriques; ane in progpess.

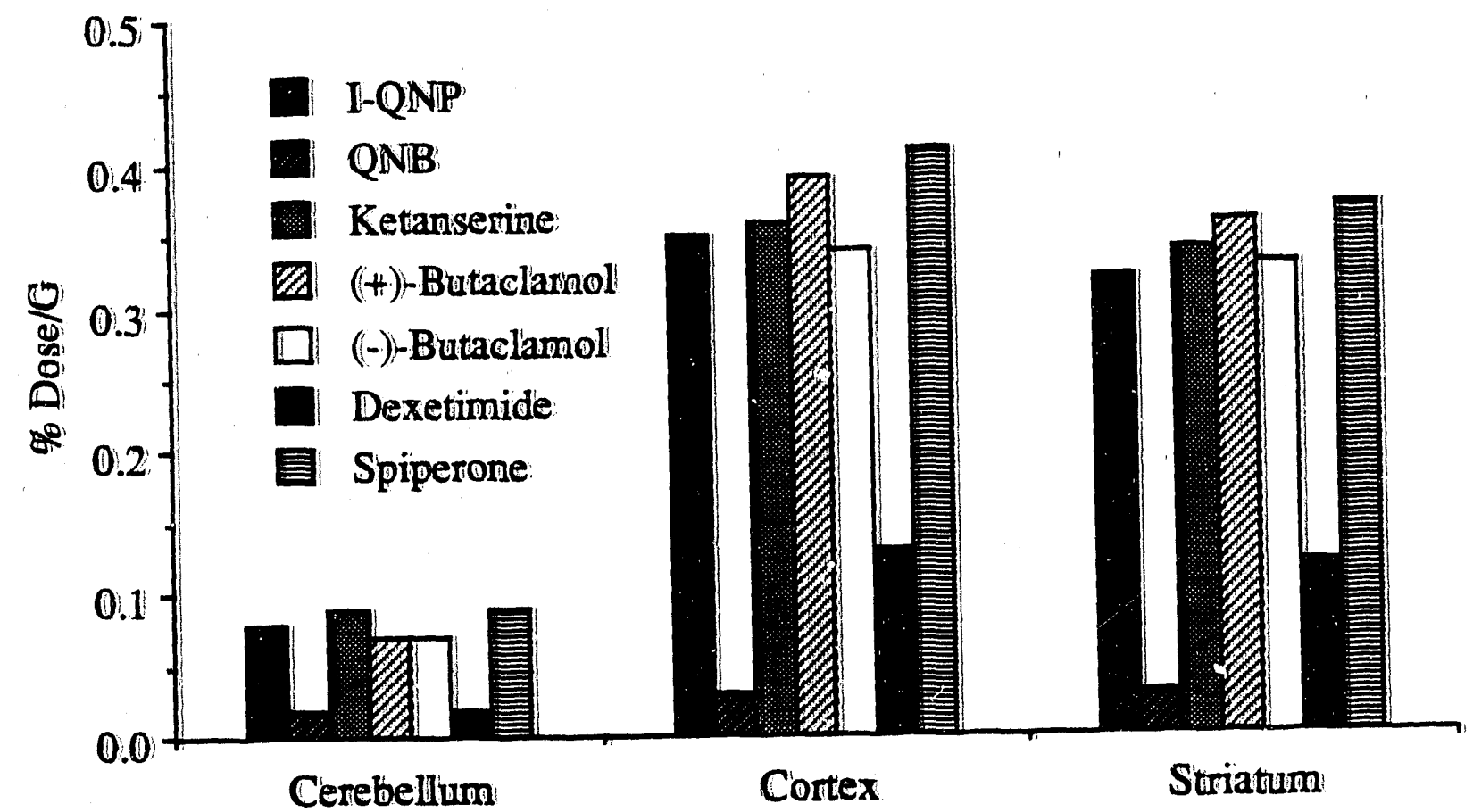

Figure 2.

AGENTS FOR MEDICAL COOPERATIVES

One shipment each of gold 1 -199 and tin-117m were supplied to Brookhaven Nationall Laboratory ( (L. Mausner, $\mathrm{Ph}$ :D.) ) to assist a continuation of BNL reseanch topics untill re-stant of the High Flux Brookhaven Reactor (HFBR). A tungsten-188/thenium-188, generator was shipped to the University/ of Bonn;, Germany/ (J. Kropp, M.D. and F. F. Knapp, Jit, Ph.D.) for collaborative studies involving thenium-188-labeled therapeutic agents. Samples of iodine125-labeled 15-(p-iodophenyl) )3-R,S-methy/pentadecanoic acid (BMMPP) and the 3,3-dimethyll analogue (DMIP'P); were shipped to the University/ of Bonn for continuing collaborative metabolic studies with an isolated rat heart nreparation (J. Kropp, M.D.). Iodine-125-labeled BMMPP and DMaPP were also supplied to Brookthaven National Laboratory/(P. Som, D. V.M.)) 
for collabonative studies: of the effects of chronic and acute cocaine intoxication on my,ocandiall fattity/ acidl uptake:.

\section{OTTHER NUCLEAR MEDICINIS GROUP' ACTINTITIES;}

\section{Publications:}

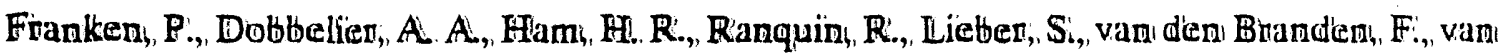

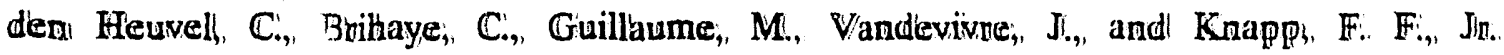
"Diserepancy/Betwat:en My,cardial Perfiusion andi Regional W/all Motion at Rest and During: Exercise in Patients with Cononary/ Aurtery/ Disease;"' Nucll Medl Commun, 12:4773-484 (119910).

Griffiths; G. L., napp, F. Fi, Jin., Callahan A. P., Chang, H.-C., Hansen,, H.. J., and Goldenberg, Di. : "Direct Radiolabeling, of Monoclonal Antibodies; with GenenatonProduced'l Rheniu;-188: for Radioimmunotherapy,", Cancen R'esearch, 5i1, 4594-4602' (11991)).

Kropp, J., Kohler; U., Knapp, F. F., Jin., Thulfaut, A., Joergens;, M., Brielk, B., andl Biensack, H.-J. "Initial Clinical Scintigraphic: Experience with 15-(p-I-123-Iodophenyl) $)$ 3-R,SMethylpentadecanoic Acidl (BMaPP) for the Diagnosis; of Coronary/ Heant Disease: ((CHD),,"' Annual Meeting of the German Society/ of Nuclear Medicine; University/ of Tuebingen, Aprill $111-13 ;, 1991$, Nuklearmedizin, $2 ;, 477(1991)$ ).

Kropp, J., Likungu, J., Kinschhoff, P.. G., Knappt, F: F., Ji., Reichmann, K., Reske, S. N., and Biersack, H.-J! "Single: Photon Emission Tomographic Imaging of Myocandiall Oxidative Metabolism with 15-(p-[1 -123) Iodophenyl)Pentadecanoic Acid in Patients: with Coronany/

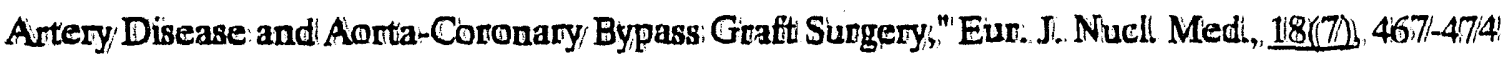
(1991).

Lambert, S. J., Kabalka, G. W., Knapp, F. F., Jr., and Srivastava, P. C. "Inductive Effect of Positively/ Charged Nitiogen on the Addition of lodine Monochlonide to Alkynamine Hydrochlorides;", J. Org. Chem,, 56, 37077-377111 (19991) 


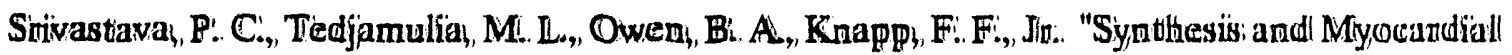

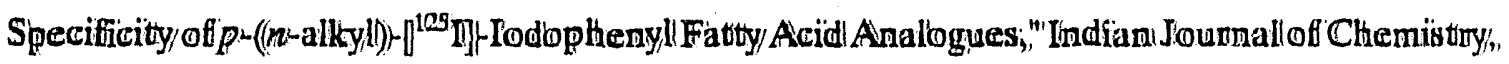
3.0B $1888.1941((1991))$.

\section{Presentations:}

Members of the Nuclear Medicine Gnoup presented and co-authoned three papens; at the recent Eunopean Association of Nuclear Medicine Congness; held in Vienna, Austritu on September $1-5,1990$.

Ambrose; K. R., Kropp, J., Lambent, C. R., Biersack, H.-J., andl Knapph, F: F:, Jir. "Back Diffiusion (BDi)) andl Rellease of Metabolites: ("X")) Contribute to W/asthout of Radioiodinated BMIPP' from Isolated Rat Heants: (RRH))."'

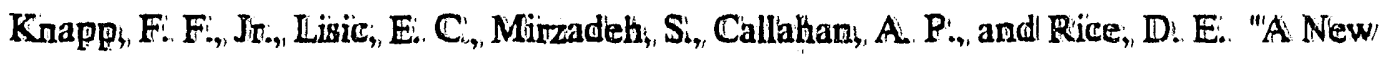
Clinical Prototype Tungsten-188/R/henium-188: Genenator to, Provide: Hight Levels: of Carrier-Free Rhenium-188; for Radioimmunotherapy/ (RAUT)!"

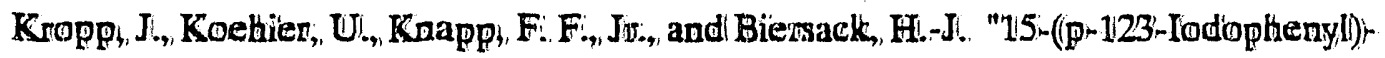
3-R,S-methylpentadecanoic (BMMPP) to Evaluate Ischemia in Patients: with: Cononary/ Artery/ Disease ((CADD))."

\section{Miscellaneous:}

F. F: Knapp, Jr. served as an external expert member of the thesis committee at the Free University/ of Brussels on September 23 , 1991, for the doctoral thesis of Phillipe $R$. Fran sn, M.D., from the Nuclear Medicine Department at Mididelheim Hospital in Antwerp, Belgium. The thesis entitled "Functional Evaluation of Ischemic Heant Disease by/ Means of First-Pass Radionuclide: Angiogfaphy'm is based on the evaluation of a lange number of patients; with the ultra-shont lived inidium-191/m radioisotope from the osmium-191//iridium$191 \mathrm{~m}$ generator developed in the ORNL, Nuclear Medicine Group. 
P. C. Srivastava has been appointed as a professor adjunct, at the University of Tennessee Biomedical School, for a tive-year term.

Members of the Nuclear Medicine Group (F. F. Knapp, Jr., S. Mirzadeh, A. P. Callahan) are organizing a symposium entitled "New Radionuclide Generator Systems for Nuclear Medicine Applications," under the auspices of the Division of Nuclear Chemistry and Techncicgy of the American Chemical Society (ACS) for the National ACS Meeting to be held in Washington, D.C., August 23-28, 1992. The proceedings of this symposium are planned for publication in the "ACS Advanues in Chemistry" series. 
INTERNIAL DISTTRIBUUTION

1. K R Ambrose

2. J. F. Allred:

3. J. T. Bell

4. T. A. Butler (Consultant)

5. A. P. Callahan

6. E. D. Collins

7. K. F. Eckerman

8. R. K. Genung

9. M. M. Goodman (Consultant)

10. G. D. Griffin

11. A Hasan

12. J. R. Hightower

13. G. W. Kabalka (Consultant)

14. S. V. Kaye

15-19: F. F. Knapp, Jr.

20. C. R. Lambert

21. S. J. Lambent

22. E. C. Lisic (Consultant)
23. D. W. McPherson

24. J C. Miller

25. S. Mirzadeh

26. B. Patton

27. G. Prosser

28. D. Pruett

29. D. W Ramey

30. D. E. Rice

31. D. E. Reichle

32. P: S. Rohwer

33. P. C. Srivastava

34-35. Central Research Librany

36. Document Record Section

37-38. Labonatory Records Dept.

39. Lab. Recrords, ORNL RC

40. ORNL Patent Section

\section{EXTERNAL DISTRIBBUTION}

41. S. J. Adelstein, M.D., Shields Warren Radiation Lab،, Boston, MA 02115.

42. H. L. Atkins, M.D., Radiology Dept, State Univ. of New York, Stony Brook, NY 11794-8460

45. H. J. Biersack, M.D., Director, Klinix fuer Nuklear Medizin, Der Universitat Bonn, Sigmund Freud Strasse 25, 5300 Bonn 1, West Germany

44. C. Brihaye, Centre de Recherches du Cyclotron, Universite de Liege, Belgium

45. A. B. Brill, M.D., Ph.D., Dept of Nuclear Medicine, Univ. of Massachusetts Medical Center, 55 Lake Avenue North, Worcester; MA 01655

46. T. F. Budinger, M.D., zmd 55/121, Lawrence Berkeley Laboratory, 1 Cyclotron Road, Berkeley, CA 94720

47. D. W. Cole, Jr., U.S. DOE, MS-ER-73, GTN, Washington, D.C. 20585

48. J. G. Davis, M.D., Medical and Heaith Sciences Division, ORAU, Oak Ridge, TN 37831

49. S. J. DeNardo, M.D., Univ. California, Davis Medical Center, Sacramento, CA 95817

50. R. F. Dannals, Division of Nuclear Medicine, Johns Hopkins Medical Institutions, Baltimore, MD 21205-2179

51. R. Dudczak, M.D., Dept. Nuclear Medicine, I. Medizinische Universitatsklinik, A-1090 Wien, Lazarettgasse 14, Vienna, Austria

52. D. R. Elmaleh, Physics Research Dept, Massachusetts General Hospital, Boston, MA 02114 
53. L. Feinendegen, Institut fur Medizin, Forschungszentnum Julich GmbH, Postfach 19113, Di5170, Julich 1, Germany

54. A. Fritzbeng, NeoRx Conporation, 410 West Hanison, Seattle, WA 981119

55. D. M. Goldenberg, M.D., Center of Molecular Medicine and Immunology, 1 Bruce Street, Newark, NJ 07:103

56. M. Guillaume, Chef de Travaux, Centre de Recherches du Cyclotron, Universite de Liege, Belgium

57. D. R. Hamilton, Directon, Division of Technical Development, OTAVCDR'H/FD A, 1901 Chapman Avenue, Rockville, MD 20857

58. J. Hiltunen, Technical Research Centre of Finland, Reactor Labonatory, Otakaani 3 A, SF-02150 Espoo, Finland

59. K. Hubnen, M.D., Depantment of Radiology, UT Memorial Hospitall, Kroxville, TN 37920:

60. A. Jones, HMS Radiology Dept., Shields Warren Radiation Labonatory, 50 Binney Street, Boston, MA 02115

61. G. Kirsch, Department of Chemistry, Universite de Metz, Metz, France

62. J. Kropp, M.D., Klinik fuer Nuklear Medizin, Der Universitat Bonn, Sigmund Freud Strasse 25, 5300 Bonn 1, West Germany

63. D. E. Kuhl, M.D., Division of Nuclear Medicine, University of Michigan Hospitals, University Hospital BIG 412/0028, 1500 E. Medical Center Drive, Ann Artbor, MI 48109-0028.

64. S. Larson, M.D., Sloan-Kettering Inst. for Cancer Research, New York, NY 10021

65. D. J. Maddalena, FRACI, Depantment of Pharmacology, Sydney University, NSW 2006, Sydney, Australia

66. Office of Assistant Manager for Energy Research and Development DOE-ORO, Oak Ridge, TN 37831

67. R. Patterson, M.D., Nuclear Cardiology; Crawford Long Hospital, 550 Peachtree Street, NE, Atlanta, GA 30365-2225

68. C. L. Partain, M.D., Professor and Vice Chairman, Dept. Radiology and Radiological Sciences, Vanderbilt University Medical Center, Nashville, TN 37232

69. R. C. Reba, M.D., 5841 S. Maryland Ave., U.C. Hospital Box 429, Chicago, IL 60637

70. M. Robbins, Mallinckrodt, Inc., 675 McDonnell Blvd., P.O. Box 5840, St. Louis, MO 63134

71. M. P. Sandler, M.D., Chief, Nuclear Medicine Section, Vanderbilt University Medical Center, Nashville, TN 37232

72. R. E. Schenter, HO-37, Westington Hanford Co., P.O. Box 1970, Richland, WA 99352

73. F. Snyder, ORAU, Oak Ridge, TN 37831

74. A. Solomon, M.D., UT MRCH, 1924 Alcoa Highway, Knoxville, TN 37920-6999

75. P. Som, DVM, Medical Department, BNL, Upton, NY 11973

76. S. C. Srivastava, Bldg. 801, Medical Dept., BNL, Upton, NY 11973

77. H. W. Strauss, M.D., Nuclear Medicine Div., Massachusetts General Hospital, Boston, MA 02114

78-88. Office of Scientific and Technical Information, DOE, Oak Ridge, TN 37831

89. F. Visser, M.D., Cardiology Dept., Free University Hospital, De Boelejaan 117, Amsterdam, The Netherlands

90. H. N. Wagner, Jr., M.D., Div. of Nuclear Medicine, Johns Hopkins Medical Institutions, $615 \mathrm{~N}$. Wolfe Street, Baltimore; MD 21205-2179

91. A. P. Wolf, BNL, Upton, NY 11973 
92. R. Wolfangel, Mallinckrodt, Inc., 675 McDonnell Blud!, P.O. Box 5840, St.. Louis, MO 631134

93. D. V. Woo, Centocon, 244 Great Valley Parkway,, Malvern, P'A 119355

94. R. W. Wood, Jr., DOE-OHER, Washington, DC 20585

95. S. Wynchank, Research Institute for Medical Biophysics (R'IMB), R'epublic of South Asfirica! 

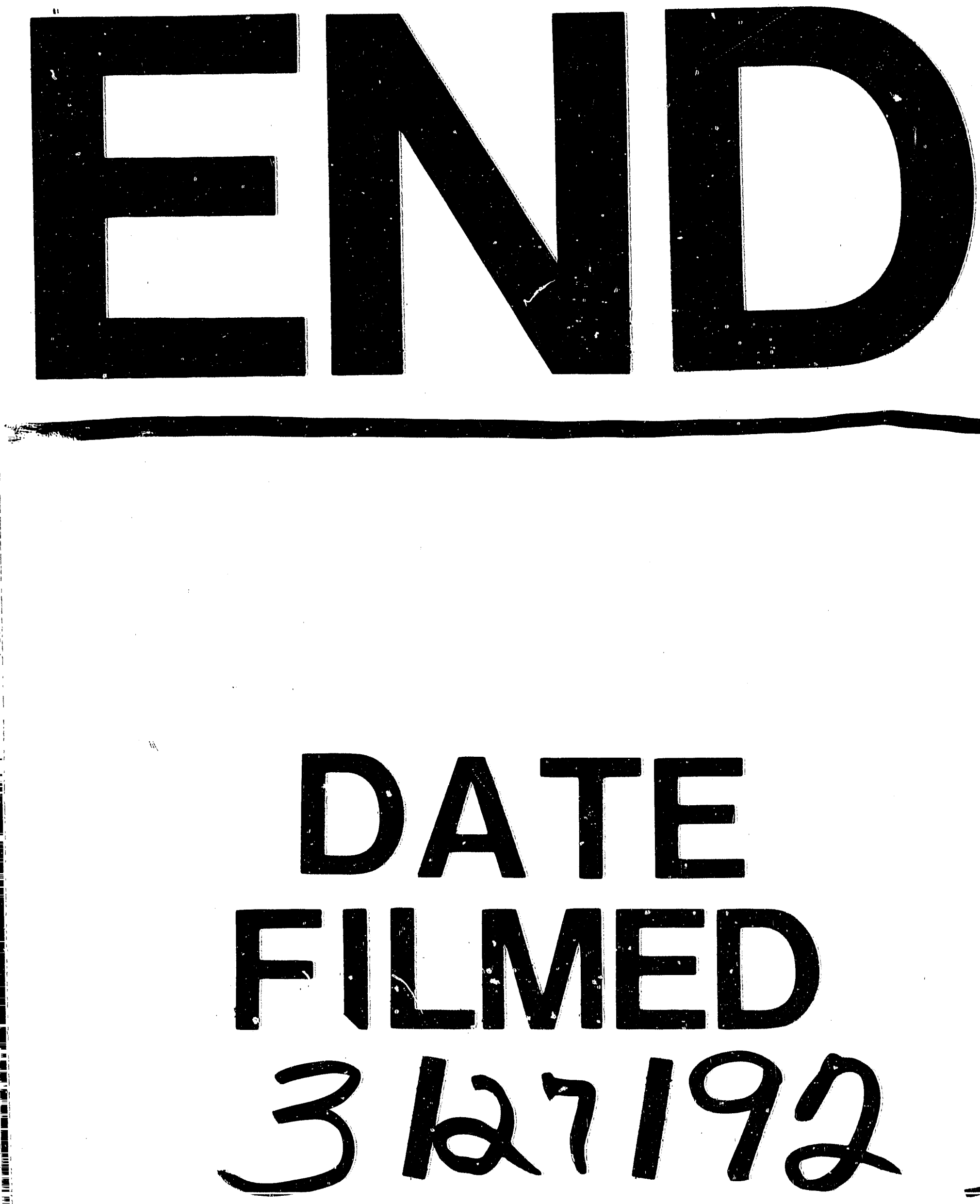


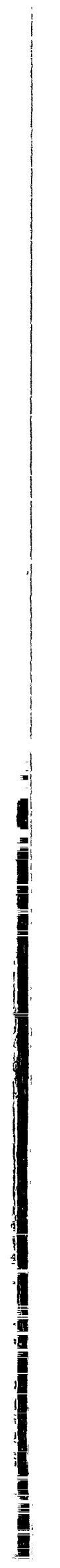

